\title{
PENGARUH KINERJA ICSR TERHADAP READABILITY ICSR MENGGUNAKAN GUNNING FOG DAN FLESCH-KINCAID INDEKS DENGAN SIZE, KINERJA KEUANGAN, LEVERAGE DAN GROWTH SEBAGAI VARIABEL KONTROL
}

\author{
Riyang Mardini \\ Program Studi Akuntansi \\ Universitas Islam Bandung \\ riyang.mardini@yahoo.com
}

\begin{abstract}
Islamic Corporate Social Responsibility is an assimilation of social responsibility that must be considered by Islamic banking in Indonesia. Islamic Corporate Social Responsibility has experienced an increase in demand from various stakeholders, this condition is the reason for Islamic banking to improve the performance of Islamic Corporate Social Responsibility and communicate it to stakeholders. In presenting its social responsibility to the public, Islamic banking is expected to provide communicative, simple, quality, and easy-to-understand information. This study investigates the effect of the performance of Islamic Corporate Social Responsibility on the readability of Islamic Corporate Social Responsibility. Size, financial performance, leverage and growth as control variables in this case. The results of the study state that the Islamic Corporate Social Responsibility performance affects the readability of Islamic Corporate Social Responsibility.
\end{abstract}

Keywords: Islamic Corporate Social Responsibility, Financial Factors, Readability, Gunning Fog Indeks, Flesch Kincaid Indeks.

\begin{abstract}
Abstrak
Islamic Corporate Social Responsibility merupakan asimilasi tanggung jawab sosial yang harus diperhatikan oleh perbankan syariah di Indonesia. Islamic Corporate Social Responsibility telah mengalami peningkatan permintaan dari berbagai pemangku kepentingan, kondisi ini menjadi alasan bagi perbankan syariah untuk meningkatkan kinerja Islamic Corporate Social Responsibility dan mengkomunikasikannya kepada para pemangku kepentingan, Dalam menyajikan pertanggungjawaban sosialnya kepada masyarakat, perbankan syariah diharapkan memberikan informasi yang komunikatif, sederhana, berualitas, dan mudah dipahami. Penelitian ini menyelidiki pengaruh kinerja Islamic Corporate Social Responsibility terhadap keterbacaan laporan Islamic Corporate Social Responsibility dengan size, kinerja keuangan, leverage dan growth sebagai variabel kontrol. Hasil penelitian menyatakan bahwa Kinerja Islamic Corporate Social
\end{abstract}


Responsibility berpengaruh terhadap Keterbacaan Islamic Corporate Social Responsibility.

\section{Kata Kunci: Islamic Corporate Social Responsibility, Faktor Keuangan, Keterbacaan, Gunning Fog Indeks, Flesch Kincaid Indeks.}

\section{PENDAHULUAN}

Perusahaan saat ini tidak lagi berhadapan dengan konsep single bottom line yang dianggap sebagai konsep yang sekedar memperhatikan profit tetapi juga dihadapkan pada konsep tripple bottom line yang memuat aspek keuangan, aspek sosial dan aspek lingkungan hidup dalam rangka memperkuat keberlanjutan perusahaan dengan membangun kerjasama antar stakeholders yang difasilitasi perusahaan untuk beradaptasi dengan lingkungannya. Konsep sustainability development inilah yang mengubah pola aktivitas bisnis dari yang semula bersifat single bottom line menjadi triple bottom line (people, planet, and profit) (Elkington, 1997).

Ketiga konsep tersebut merupakan dasar yang digunakan untuk mengukur nilai kesuksesan suatu perusahaan dengan tiga kriteria yaitu ekonomi, lingkungan, dan sosial, konsep tersebut didukung oleh teori legitimasi yang berfokus pada interaksi yang terjadi antara kepatuhan perusahaan pada peraturan yang ada di masyarakat. Teori legitimasi menetapkan bahwa perusahaan harus berusaha mengejar legitimasi moral yang diberikan oleh para pemangku kepentingannya dengan mempertahankan strategi dan operasi bisnis yang bertanggung jawab secara sosial (Scherer \& Palazzo, 2011).

ISO 26000 (Guidance Standard on Social Responsibility) telah dirumuskan pada bulan September tahun 2004 merupakan pedoman yang mengatur pelaksanaan Corporate Social Responsibility (CSR) bagi semua perusahaan (www.isoindonesiacenter.com). Pada sektor perbankan khususnya di Indonesia tanggung jawab sosial perusahaan ini merupakan sebuah komitmen perusahaan yang bertujuan untuk memberikan nilai tambah kepada semua pemangku kepentingan seperti yang dinyatakan dalam UU No 40 Tahun 2007 tentang Perseroan Terbatas serta UU No 25 Tahun 2007 tentang Penanaman Modal bahwa setiap perusahaan yang menjalankan kegiatan usaha yang berkaitan dengan sumber daya alam diwajibkan melaksanakan tanggung jawab sosial dan lingkungan. Sektor perbankan memang tidak secara langsung melakukan kegiatan usaha yang 
berkaitan langsung dengan pemanfaatan sumber daya alam namun kegiatan usahanya sangat berdampak pada fungsi kemampuan sumber daya alam.

Perkembangan CSR dalam ekonomi Islam juga berdampak pada peningkatan perhatian masyarakat terhadap perusahaan-perusahaan yang berorientasi pada prinsip syariah khususnya sektor perbankan syariah di Indonesia. Perusahaan manapun yang mengklaim mendasarkan operasinya pada prinsip-prinsip syariah harus secara alami mempraktikan Islamic Corporate Social Responsibility, asimilasi tanggung jawab sosial harus mendapat pertimbangan terbaik dari pemilik bisnis untuk mendorong perusahaanperusahaan Islam ke tingkat yang lebih tinggi dalam mengamankan pelanggan (Dusuki, 2008). Islamic Corporate Social Responsibility (ICSR) telah mengalami peningkatan permintaan dari berbagai pihak pemangku kepentingan baik itu konsumen, karyawan, pemegang saham, komunitas, dan lingkungan dalam segala aspek, kondisi ini meningkatkan tekanan bagi organisasi untuk meningkatkan kegiatan CSR dan mengkomunikasikannya kepada para pemangku kepentingan. Informasi CSR yang relevan di pasar modal akan mencegah terjadinya asymetric information.

SFAC No.1 alinea ke-34 FASB menetapkan tujuan pelaporan keuangan sehubungan dengan fungsi informasi keuangan untuk pengambilan keputusan. Informasi tersebut mencakup informasi keuangan dan non-keuangan, artinya seluruh aspek informasi perusahaan sangat diperlukan oleh semua pemangku kepentingan. Annual report merupakan informasi utama yang digunakan oleh investor untuk pengambilan keputusan investasi. Dalam menyajikan pertanggungjawaban sosialnya kepada masyarakat, perusahaan diharapkan memberikan informasi yang komunikatif, sederhana, berkualitas dan mudah dipahami dalam rangka mendapatkan dukungan seluruh stakeholder dalam persaingan global.

UNESCO menyatakan bahwa negara Indonesia menduduki urutan kedua dari bawah dalam literasi dunia (menulis dan membaca) yang masih rendah yakni $0.001 \%$ Artinya dari 1000 orang Indonesia hanya 1 orang yang memiliki kemampuan literasi yang baik (www.kominfo.go.id), dengan alasan tersebut sepatutnya manajemen mempertimbangkan keterbacaan laporannya agar lebih mudah dipahami. Selanjutnya, keterbacaan (readable) merupakan kemudahan untuk membaca dan memahami suatu 
teks atau naskah secara kuantitatif, indeks keterbacaan tersebut dapat diuji menggunakan beberapa formula, diantaranya Gunning Fog Index dan Flesch-Kincaid Index.

Penelitian Wang et.al (2017) menyatakan bahwa kinerja sosial berhubungan signifikan terhadap indeks keterbacaan yang digunakan yaitu Gunning Fog Index dan Flesch-Kincaid Index dengan menggunakan variabel kontrol ukuran perusahaan, kinerja keuangan, leverage, growth, kompleksitas, jumlah segmen, litigasi perusahaan, tata kelola perusahaan, jenis kelamin, usia dan masa kerja. Penelitian (Ahmed, 2013) mengungkapkan tingkat keterbacaan laporan tahunan dari seluruh Islamic Bank terpilih dunia diantaranya Dubai, Bahrain, Malaysia dan Iran, hasilnya menyatakan bahwa secara keseluruhan laporan tahunan tidak mudah dipahami. Bawono et al (2019) mengungkapkan bahwa tidak ada keterkaitan antara Corporate Social Responsibility dengan kualitas keterbacaan yang menggunakan ukuran perusahaan, kompleksitas bisnis, leverage, pertumbuhan, dan karakteristik CEO sebagai variabel kontrol. Research gap ini membuat peneliti ingin mengetahui lebih jauh mengenai pengaruh antara Kinerja Islamic Corporate Social Responsibility dengan keterbacaan (readability) laporan Islamic Corporate Social Responsibility dengan size, kinerja keuangan, leverage dan growth sebagai variabel kontrol.

\section{LANDASAN TEORI}

\subsection{Islamic Corporate Social Responsibility}

Pandangan Islam tentang CSR merupakan pendekatan yang menyeluruh berdasarkan pada ajaran Al-Qur'an dan sunnah. CSR dalam pandangan Islam memberikan alternatif kerangka kerja yang lebih baik dalam mengatur interaksi manusia dan alam sekitarnya (Ahmad, 2002). Dalam perspektif Islam, CSR memiliki arti yang sangat luas yang mengutamakan nilai keimanan pada Allah (taqwa) dalam segala situasi, karena setiap orang dalam suatu entitas harus berperan dan bertanggung jawab sebagai pelayan dan wakil (Dusuki, 2008).

Penelitian ini menggunakan Indeks Pengungkapan Islamic Corporate Social Responsibility berdasarkan penelitian sebelumnya yang dilakukan oleh Haniffa (2002), Ousama dan Fatima (2006), Othman dan Thani (2010). Enam indeks pengungkapan tersebut adalah: 
1. Finance and investment;

2. Product/ services;

3. Employee;

4. Society;

5. Environment;

6. Corporate governance.

\section{ICSR Index}

\section{A. Finance And Investment}

1. Non riba activities;

2. Uncertainty ( Non Gharar Activity);

3. Zakat: zakat deduction method/beneficiaries of zakat;

4. Bad debt relief policy;

5. Current Value Balance Sheet (CVBS);

6. Value Added Statement (VAS);

\section{B. Product And Service Theme}

7. Conformity to the principles of green products;

8. Products with halal status;

9. Quality products and safe;

10. Policy on customer complaints;

\section{Employee Theme}

11. Policies regarding employee working hours, holidays, and other benefits;

12. Training and education/Human Capital Development;

13. Employees have the same career opportunities;

14. Employee involvement in the company;

15. Work safety guarantee (insurance);

16. Comfortable work environment;

17. Hiring employees with other special-interest-group (i.e. handicapped, exconvicts, former drug-addicts);

18. Congregational prayers;

19. Permission to perform prayers, fasting during ramadhan on their working day;

20. There is a place of worship;

\section{Society Theme}

21. The company makes donations and saddaqa;

22. The company provides waqaf;

23. The company provides benevolence loans (qard hassan);

24. Employee willingness in carrying out environmental activities;

25. Provide scholarships;

26. Job vacancies;

27. Youth development;

28. Provide assistance to underprivileged communities; 
29. Care for children;

30. Do charity work, give gifts, and be active in social activities;

31. Provide sponsorship for health/recreational/sports/cultural activities;

\section{E. Environment Theme}

32. Carry out environmental conservation activities;

33. Care for endangered animals;

34. Do not carry out activities that pollute the environment;

35. Provide education to employees about environmental pollution;

36. Environmentally friendly product/process;

37. Conduct environmental audits/Independent Verification Statement;

38. Environmental Management System and Policy;

\section{F. Corporate Governance Theme}

39. Company has sharia compliance status;

40. Muslim and non-Muslim share ownership structures;

41. Muslim and non-Muslim BOD members;

42. Declared prohibited activities: monopoly, hoarding, cheating, gambling;

43. Anti-corruption policies.

Sumber: Haniffa (2002), Ousama dan Fatima (2006), Othman dan Thani (2010).

\subsection{Readability ICSR}

Readability adalah kemudahan pembaca untuk memahami teks tertulis. Dalam bahasa alami, keterbacaan teks bergantung pada isinya (kompleksitas kosakata dan sintaksisnya) dan penyajiannya (seperti aspek tipografi seperti ukuran font, tinggi baris, dan panjang baris) (Miles, 1963). Keterbacaan memiliki banyak teknik untuk mengukurnya, dalam penelitian ini digunakan Gunning Fog Index dan Flesch-Kincaid Index untuk mengukur keterbacaan laporan ICSR yang terdapat pada annual report perusahaan.

Dalam pengungkapan annual report perusahaan, ada beberapa elemen penting yang harus diperhatikan diantaranya konten apakah yang disajikan, kapan waktu penyajian, dan bagaimana pengungkapan tersebut disajikan (Courtis, 2004). Kegunaan laporan bergantung pada keterbacaan yang mudah dipahami, serta elemen dalam penulisan laporan sebaiknya tidak menghalangi pemahaman pembaca. Elemen-elemen tersebut diantaranya konten, format, organisasi dan gaya penulisan. Dalam laporan ICSR setidaknya ada dua variabel yang digunakan sebagai indeks yang tepat dalam memperkirakan kesulitan keterbacaan diantaranya panjang kata dan panjang kalimat. 


\section{Kerangka Pemikiran}

Teori agensi menjelaskan hubungan keagenan antara manajemen perusahaan sebagai agen dan pemilik sebagai principal. Hubungan keagenan ini seringkali dapat menimbulkan konflik kepentingan (Jensen dan Meckling, 1976). Disatu sisi, pihak manajemen dituntut untuk memaksimalkan keuntungan perusahaan, dilain pihak manajemen dituntut pula untuk memberikan informasi yang lebih rinci mengenai informasi non-financial perusahaan seperti laporan tanggung jawab sosial. Informasi yang lebih lengkap yang dimiliki oleh manajemen perusahaan memberikan dampak adanya asimetri informasi (information asymmetric). Manajer sebagai pengelola berkewajiban untuk memberikan sinyal mengenai kondisi perushaan kepada pemilik namun informasi yang disampaikan terkadang seringkali tidak sesuai dengan kondisi perusahaan yang sebenarnya (Hendriksen dan Van Breda, 1991).

Laporan tahunan dengan keterbacaan yang tinggi dapat lebih meringankan tingkat asimetri informasi yang dihadapi oleh pemangku kepentingan termasuk pemegang saham dan meningkatkan transparansi informasi perusahaan (Luo et al, 2018). Laporan CSR memainkan peranan penting dalam mengurangi asimetri informasi yang relevan kepada investor dengan penggunaan properti tekstual (keterbacaan dan nada) (Shuili dan Kun, 2020). Perusahaan yang memiliki laporan tahunan yang mudah dibaca memiliki tingkat kualitas pengungkapan informasi yang lebih tinggi yang dapat mengurangi tingkat asimetri informasi yang dihadapi oleh pemegang saham dan membantu manajemen untuk memberikan informasi yang lebih berkualitas.

Teori legitimasi menetapkan bahwa kegiatan CSR adalah salah satu cara untuk memenuhi tujuan CSR dalam memenuhi legitimasi moral yang diberikan oleh agen sosial mereka dengan mempertahankan strategi dan operasi bisnis yang bertanggungjawab secara sosial untuk mempertahankan legitimasi (Scherer dan Palazzo, 2011). Untuk mencapai citra perusahaan yang positif perusahaan dapat memanipulasi keterbacaan dari pengungkapan narasi CSR untuk memberi penekanan pada informasi positif dan mengurangi informasi negatif (Wang et al, 2017). Dengan demikian teori legitimasi memberikan motivasi kepada perusahaan agar mengungkapkan informasi yang positif kepada publik sebagai sarana untuk mengejar legitimasi publik. 
Berdasarkan penelitian yang dilakukan oleh Sheikh dan Ameer (2010) pada perusahaan yang terdaftar di Bursa Malaysia, manajemen dari perusahaan yang memiliki kinerja CSR yang buruk sengaja memilih bahasa yang sulit dalam menyajikan laporan tahunan. Ahmed et al (2013) menyatakan bahwa perusahaan perbankan memiliki lebih banyak 'pekerjaan' yang harus dilakukan pada laporan tahunannya agar dapat dimengerti oleh berbagai pemangku kepentingan. Penelitian Wang et al (2017) menyatakan bahwa perusahaan dengan kinerja CSR yang lebih baik cenderung menggunakan bahasa yang sederhana untuk mengungkapkan pencapaian CSR mereka sebagai upaya untuk menekankan informasi positif. Penelitian tengtang CSR dan keterbacaannya telah dilakukan oleh Bawono et al (2019) dan Wang et al (2017) menggunakan variabel kontrol kompleksitas, size, kinerja keuangan, jumlah segmen, tata kelola, leverage, growth, karakteristik CEO. Penelitian ini menggunakan empat variabel kontrol yaitu size, kinerja keuangan, leverage dan growth yang dipilih berdasarkan kesesuaian dengan data yang terdapat di perusahaan perbankan serta menggunakan variabel independen Islamic Corporate Social Responsibility. Berdasarkan pada kerangka pemikiran di atas, maka hipotesis penelitian ini adalah:

H1 : Kinerja ICSR berpengaruh terhadap Keterbacaan Laporan ICSR

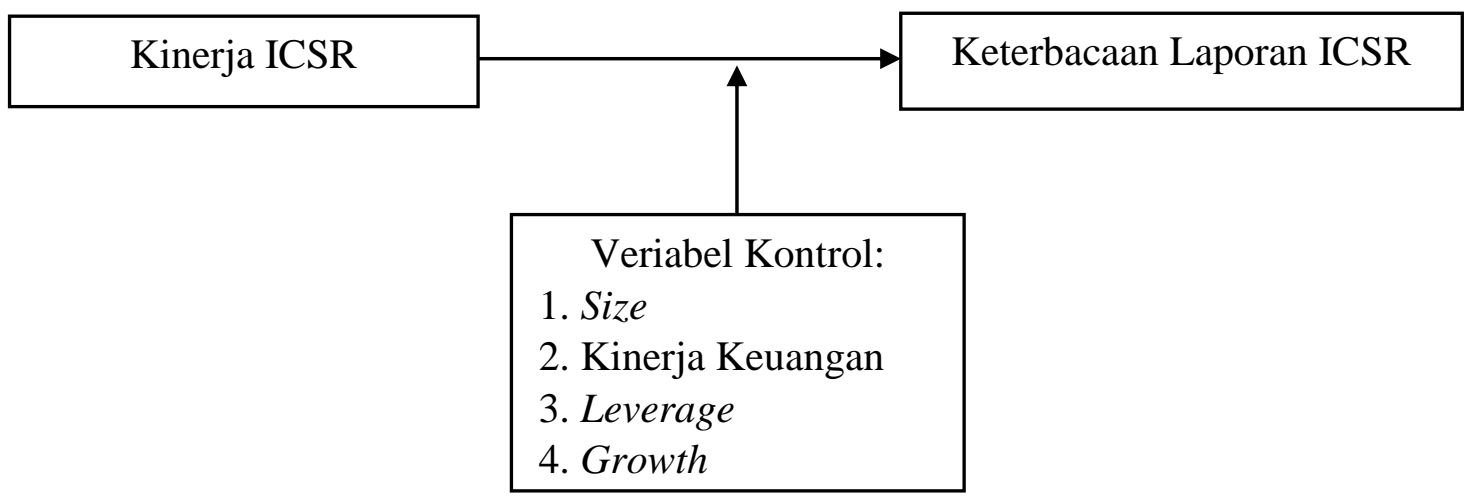

Gambar 1 Kerangka Penelitian

\section{METODE PENELITIAN}

Metode penelitian yang digunakan adalah metode kuantitatif, metode penelitian kuantitatif dilandaskan pada positivism theory yang berpendapat bahwa realita, gejala, atau sebuah fenomena dapat dikelompokkan, tetap, dapat diukur, dan merupakan pola hubungan yang bersifat sebab akibat (Sugiyono, 2013:13). Teknik pengumpulan data dilakukan dengan menggunakan data sekunder. Data yang digunakan dalam penelitian 
ini adalah laporan tahunan (annual report) perusahaan perbankan syariah selama tahun 2017-2019. Jumlah objek penelitian yang digunakan dalam penelitian ini adalah sebanyak 14 sektor perbankan syariah di Indonesia dalam rentang waktu 3 tahun, sehingga jumlah sampel yang digunakan adalah sebanyak 42 sampel.

Indeks Islamic Corporate Social Responsibility dalam penelitian ini berjumlah 43 item. Masing-masing item pengungkapan memiliki nilai 1 jika diungkapkan atau 0 jika tidak diungkapkan. Nilai tersebut kemudian dijumlahkan sehingga memiliki skor maksimal berjumlah 43 dan skor terendah bernilai 0 untuk setiap perusahaan dalam satu tahun. Langkah berikutnya skor pengungkapan ICSR dihitung sebagai berikut:

$$
\text { ICSRDj } \quad=\frac{\sum X I j}{n j}
$$

ICSRD : Islamic Corporate Social Responsibility Disclosure Index perusahaan j

$\mathrm{Nj} \quad$ : Jumlah seluruh item indeks perusahaan $\mathrm{j}, \mathrm{nj}=43$

Xij : Nilai 1 = apabila item tersebut (i) diungkapkan; Nilai $0=$ apabila item (i) tidak diungkapkan, Sehingga $0 \leq \mathrm{I} \mathrm{j} \geq 1$.

Variabel keterbacaan (readability) dalam penelitian ini menggunakan 2 jenis indeks uji keterbacaan yaitu Gunning Fog Index dan Flesch-Kincaid Index. Gunning Fog Index merupakan formula keterbacaan yang menggunakan indikator jumlah kata, jumlah kalimat, dan jumlah kata kompleks. Skala pengukuran keterbacaan menjadi 5 interval tingkatan dari mudah hingga sulit. Penilaian Gunning Fog Index menggunakan formula sebagai berikut:

$$
\mathrm{GFI}=0,4\left(\frac{A}{k}+\frac{100}{A} S\right)
$$

GFI : Gunning Fog Index
A : Jumlah kata
$\mathrm{k} \quad$ : Jumlah kalimat
S : Jumlah kompleksitas kata (Gunning, 1952)

Flesch-Kincaid Index merupakan formula keterbacaan yang diukur berdasarkan indikator jumlah kalimat, jumlah huruf dalam kata, jumlah suku kata dalam kata dan kalimat. Rumus Flesch-Kincaid Index adalah sebagai berikut:

$$
\mathrm{FKI}=0.39\left(\frac{A}{k}\right)+11.8\left(\frac{S}{A}\right)-15.5
$$


FKI : Flesch Kincaid Index
A : Jumlah kata
$\mathrm{k} \quad$ : Jumlah kalimat
S : Jumlah kompleksitas kata (Kincaid et al 1975)

Setelah mendapatkan indeks dari masing-masing formula, kemudian membagi indeks keterbacaan tersebut menjadi 5 skala interval.

Pengukuran variabel kontrol yang digunakan dalam penelitian adalah sebagai berikut:

$$
\begin{array}{ll}
\text { Size } & =\operatorname{Ln}(\text { Total Asset }) \\
\text { Kinerja Keuangan } & =\frac{\text { Net Income }}{\text { Total Asset }} \times 100 \% \\
\text { Leverage } & =\frac{\text { Total Liability }}{\text { Total Asset }} \times 100 \% \\
\text { Growth } & =\frac{\text { Total Asset } t-\text { Tatal Asset }(t-1)}{\text { Total Asset }(t-1)}
\end{array}
$$

\section{HASIL PENELITIAN}

Uji Normalitas

\section{Tabel 1}

\section{Hasil Uji Normalitas}

Unstandardized

Residual

\begin{tabular}{llr}
\hline $\mathrm{N}$ & & 42 \\
\hline Normal Parameters & Mean & $0 \mathrm{E}-7$ \\
\cline { 2 - 3 } & Std. Deviation & 4.70136139 \\
\hline Most Extreme Differences & Absolute & .187 \\
\cline { 2 - 3 } & Positive & .187 \\
\cline { 2 - 3 } & Negative & -.130 \\
\hline Test Statistic & & .814 \\
\hline Asymp. Sig. (2-tailed) & & .386 \\
\hline
\end{tabular}

a. Test distribution is normal.

b. Calculated from data.

Sumber: Pengolahan Data SPSS 24

Uji asumsi klasik dengan uji normalitas terlebih dahulu dilakukan sebelum pengujian hipotesis untuk mengetahui apakah data yang digunakan berdistribusi normal atau tidak. Kolmogorov-Smirnov (KS) digunakan dalam uji normalitas penelitian ini dengan tingkat signifikansi sebesar 5\%, artinya data dapat dikatakan berdistribusi normal apabila nilai probability value ( $P$-value) lebih besar dari 0.05 atau $5 \%$. 
Dari tabel 1 diatas diperoleh nilai signifikansi $(p)$ sebesar $0.386(p>0.05)$ maka dapat disimpulkan bahwa data yang digunakan pada penelitian ini berdistribusi normal.

\section{Uji Heteroskedastisitas}

\section{Tabel 2}

Hasil Uji Heteroskedastisitas

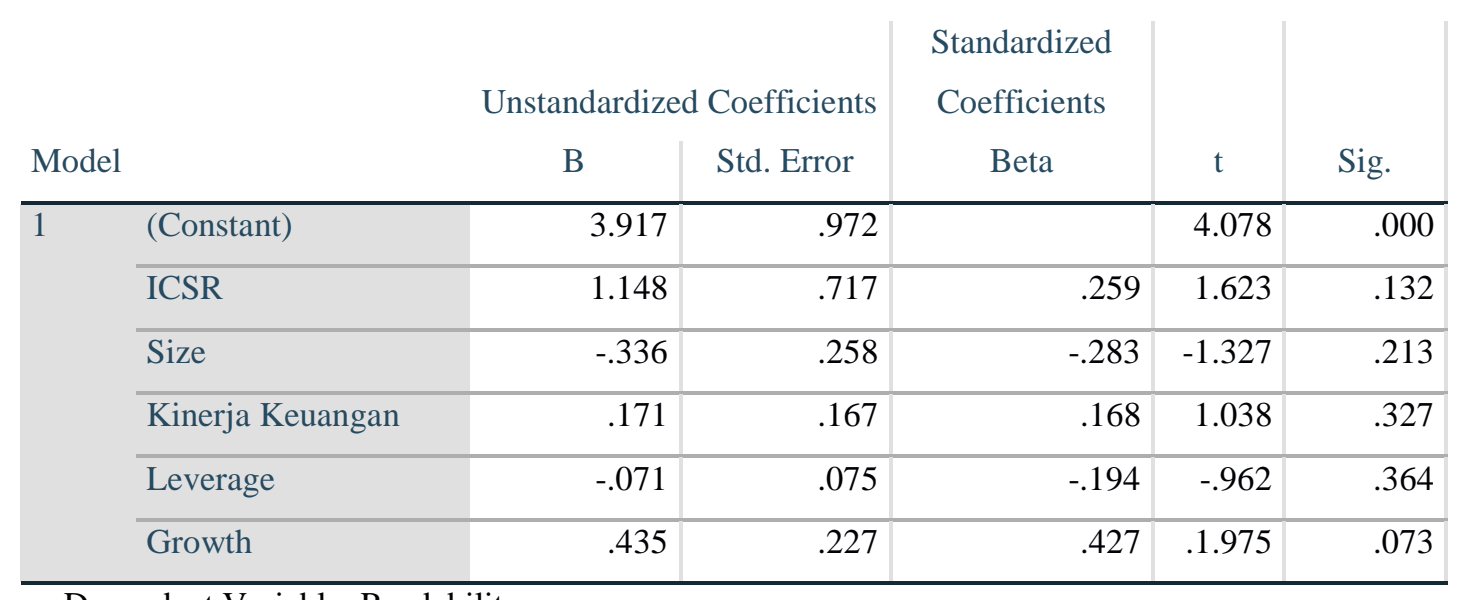

a. Dependent Variable: Readability

\section{Sumber: Pengolahan Data SPSS 24}

Uji asumsi klasik dengan heteroskedastisitas bertujuan untuk mendeteksi terjadinya ketidaksamaan variance dari residual satu pengamatan ke pengamatan yang lain. Ghozali (2016:134) menyatakan bahwa model regresi yang baik adalah homokedastisitas. Tabel 2 diatas menggunakan pengujian glesjer, dengan nilai probabilitas lebih tinggi dari nilai signifikansinya (tingkat kepercayaan yang digunakan $5 \%$ atau 0.05) maka dapat disimpulkan bahwa tidak terjadi heteroskedastisitas dalam model regresi yang digunakan.

\section{Uji Autokorelasi}

Uji autokorelasi digunakan untuk pengujian data time series, uji autokorelasi merupakan pengujian asumsi klasik dalam regresi yang menguji apakah dalam model regresi linier tersebut variabel dependen yang digunakan berkorelasi dengan dirinya sendiri atau tidak, baik dengan periode saat ini ataukah periode sebelumnya. Berdasarkan hasil pengujian autokorelasi pada tabel 3 dibawah ini, diketahui bahwa nilai Asymp. Sig (2-tailed) sebesar 0.186 yaitu lebih besar dari 0.05 maka tidak terdapat gejala atau masalah autokorelasi. 
Tabel 3

\section{Hasil Uji Autokorelasi}

\begin{tabular}{lr} 
& Unstandardized Residual \\
\hline Test Value $^{\mathrm{a}}$ & -.29271 \\
\hline Cases $<$ Test Value & 21 \\
\hline Cases $>=$ Test Value & 21 \\
\hline Total Cases & 42 \\
\hline Number of Runs & 17 \\
\hline Z & 1.406 \\
\hline Asymp. Sig. (2-tailed) & .186 \\
\hline
\end{tabular}

Sumber: Pengolahan Data SPSS 24

\section{Hasil Uji Regresi Berganda}

\section{Tabel 4}

\section{Hasil Uji Regresi}

\begin{tabular}{|c|c|c|c|c|c|c|c|c|}
\hline & & \multicolumn{2}{|c|}{$\begin{array}{l}\text { Unstandardized } \\
\text { Coefficients }\end{array}$} & \multirow{2}{*}{$\begin{array}{c}\text { Standardized } \\
\text { Coefficients } \\
\text { Beta } \\
\end{array}$} & \multirow[b]{2}{*}{$\mathrm{t}$} & \multirow[b]{2}{*}{ Sig. } & \multicolumn{2}{|c|}{$\begin{array}{l}\text { Collinearity } \\
\text { Statistics }\end{array}$} \\
\hline \multicolumn{2}{|c|}{ Model } & B & Std. Error & & & & Tolerance & VIF \\
\hline \multirow[t]{2}{*}{1} & (Constant) & 1.076 & .848 & & 1.285 & .222 & & \\
\hline & ICSR & .938 & .862 & .213 & 1.092 & .298 & 1.009 & 1.011 \\
\hline \multirow[t]{6}{*}{2} & (Constant) & 3.917 & .972 & & 4.078 & .000 & & \\
\hline & ICSR & 1.142 & .717 & .259 & 1.623 & .132 & .979 & 1.056 \\
\hline & Size & -.336 & .258 & -.283 & -1.327 & .213 & .548 & 1.889 \\
\hline & $\begin{array}{l}\text { Kinerja } \\
\text { Keuangan }\end{array}$ & .161 & .167 & .168 & 1.038 & .327 & .981 & 1.043 \\
\hline & Leverage & -.061 & .075 & -.194 & -.962 & .364 & .635 & 1.612 \\
\hline & Growth & .435 & .227 & .427 & 1.975 & .073 & .511 & 1.977 \\
\hline
\end{tabular}

a. Dependent Variable: Readability

Sumber: Pengolahan Data SPSS 24

Uji regresi berganda merupakan suatu pengujian yang dipergunakan untuk membuat suatu persamaan yang menghubungkan antara variabel dependen (Y) dengan variabel independen (X). Dari perhitungan tabel 4 di atas, maka dapat dibentuk persamaan regresi berganda sebagai berikut ini: 


\section{Readability = 3,917 + 1,142ICSR- 0,336SIZE + 0,161KINERJAKEUANGAN - 0,061LEVERAGE + 0.435GROWTH+\&}

Interpretasi hasil regresi berganda dari persamaan di atas adalah sebagai berikut:

1. Konstanta (a) sebesar 3,917 adalah apabila semua variabel independen yang lain dianggap tidak mengalami perubahan bernilai 0 , maka variabel Readability sebesar 3,917.

2. Koefisien regresi ICSR (+) positif sebesar 1,142 sehingga artinya, setiap penambahan ICSR sebesar 1 maka Readability mengalami peningkatan sebesar 1,142 .

3. Koefisien regresi Size (-) negative sebesar -0,336 sehingga artinya, setiap penambahan Size sebesar 1 maka Readability mengalami penurunan sebesar 0,336 .

4. Koefesien regresi Kinerja Keuangan (+) positif sebesar 0,161 sehingga artinya, setiap penambahan Kinerja Keuangan sebesar 1 maka Readability mengalami peningkatan sebesar 0,161 .

5. Koefisien regresi Leverage (-) negative sebesar -0,061 sehingga artinya, setiap penambahan Leverage sebesar 1 maka Readability mengalami penurunan sebesar 0,061 .

6. Koefisien regresi Growth (+) positif sebesar 0,435 sehingga artinya, setiap penambahan Growth sebesar 1 maka Readability mengalami penambahan sebesar 0,435 .

\section{Hasil Uji Hipotesis}

\section{Uji Simultan (Uji F)}

Pengujian simultan dipergunakan untuk mengetahui seberapa besar pengaruh dari keseluruhan variabel penelitian secara bersama-sama atau simultan terhadap variabel dependen (Ghozali, 2016). Dari tabel 5 di bawah, nilai F hitung pada model kedua setelah variabel kontrol dimasukkan ke dalam model adalah sebesar 3,994.

Nilai F tabel pada $\alpha=0.05$ merupakan kombinasi dari $\mathrm{k}-1=6-1=5$ dan N-k $=42$ $6=36$ sebesar 0,329 (F hitung > F tabel) maka dapat disimpulkan bahwa variabel ICSR, 
Size, Kinerja Keuangan, Leverage, dan Growth secara bersama-sama (simultan) berpengaruh terhadap variabel Readability.

Tabel 5

\section{Hasil Uji Simultan (Uji F)}

\begin{tabular}{|c|c|c|c|c|c|c|}
\hline \multicolumn{2}{|c|}{ Model } & $\begin{array}{l}\text { Sum of } \\
\text { Squares }\end{array}$ & $\mathrm{df}$ & Mean Square & $\mathrm{F}$ & Sig. \\
\hline \multirow[t]{3}{*}{1} & Regression & .840 & 1 & .840 & 1.197 & $.298^{\mathrm{b}}$ \\
\hline & Residual & 19.583 & 40 & .711 & & \\
\hline & Total & 20.411 & 41 & & & \\
\hline \multirow[t]{3}{*}{2} & Regression & 9.262 & 5 & 1.862 & 3.994 & $.021^{\mathrm{c}}$ \\
\hline & Residual & 11.161 & 36 & .477 & & \\
\hline & Total & 20.411 & 41 & & & \\
\hline
\end{tabular}

a. Dependen Variable: Readability

b. Predictors: (Constant), ICSR

c. Predictors: (Constant), Growth, Leverage, ICSR, Kinerja Keuangan, Size

Sumber: Pengolahan Data SPSS 24

\section{Uji Koefisien Determinasi $\left(\mathbf{R}^{2}\right)$}

Tabel 6

\section{Hasil Uji Koefisien Determinasi}

\begin{tabular}{|c|c|c|c|c|}
\hline Model & $\mathrm{R}$ & R Square & Adjusted R Square & $\begin{array}{l}\text { Std. Error of the } \\
\text { Estimate }\end{array}$ \\
\hline 1 & $.213^{\mathrm{a}}$ & .053 & .018 & .84401 \\
\hline 2 & $.673^{\mathrm{b}}$ & .465 & .352 & .68342 \\
\hline
\end{tabular}

a. Predictors: (Constant), ICSR

b. Predictors: (Constant), Growth, Leverage, ICSR, Kinerja Keuangan, Size

c. Dependent Variable: Readability

Sumber: Pengolahan Data SPSS 24

Uji koefisien determinasi $\left(\mathrm{R}^{2}\right)$ bertujuan untuk mengetahui seberapa jauh kemampuan model dalam menerangkan variabel-variabel dependen. Berdasarkan tabel 6 di atas pada kolom Adjusted $R$ Square $\left(\mathrm{R}^{2}\right)$ menunjukkan nilai sebelum ditambahkannya 
variabel kontrol kedalam model, nilai koefisien determinasi meningkat dari 0,018 menjadi 0,352. Hal ini berarti bahwa kontribusi seluruh variabel independen (ICSR, Size, Kinerja Keuangan, Leverage dan Growth) dalam menjelaskan variabel dependen (Readability) adalah sebesar 35\% dan sisanya sebesar 65\% dijelaskan oleh variabel lain di luar model penelitian ini.

\section{KESIMPULAN}

Perkembangan Corporate Social Responsibility semakin dibutuhkan oleh masyarakat dan lingkungan mengubah paradigma perusahaan diberbagai sektor khususnya perbankan untuk mengubah konsepnya menjadi triple bottom line. Bagi sektor perbankan syariah wajib mendasarkan tanggung jawab sosialnya dengan menyeluruh dari berbagai aspek, keuangan, jasa, karyawan, lingkungan dan tata kelola yang berlandaskan syariah. Dengan penerapan Islamic Corporate Social Responsibility dan didukung oleh transparansi laporan perusahaan yang semakin berkualitas, komunikatif, readable akan lebih mudah mendapatkan dukungan dari berbagai pemangku kepentingan.

Penelitian ini telah menguji pengaruh Kinerja Islamic Corporate Social Responsibility dengan Keterbacaan Laporan Islamic Corporate Social Responsibility dengan menggunakan variabel kontrol (Size, Kinerja Keuangan, Leverage dan Growth) pada sektor perbankan syariah di Indonesia. Hasil penelitian menyatakan bahwa dengan menambahkan variabel kontrol ke dalam model regresi penelitian ini semakin memperkuat pengaruh antara variabel Kinerja ICSR dengan Keterbacaan ICSR.

\section{DAFTAR PUSTAKA}

Ahmad, Khaliq. 2002. Islamic Ethics in a Changing Environment for Managers, in Abul Hasan M. Sadeq (ed.), Ethics in Business and Management: Islamic and Mainstream Approaches. London: Asean Academic Press.

Aishah, Sheikh Abu Bakar dan Rashid Ameer. 2011. Readability of Corporate Social Responsibility Communication in Malaysia. Corporate Social Responsibility and Environmental Management Corp. Soc. Responsib. Environ. Mgmt. 18, 5060 (2011).

Courtis JK. 2004. Corporate report obfuscation: artefact or phenomenon. The British Accounting Review 36: 291-312.

Dusuki, A.W. 2008. What Does Islam Say About Corporate Social Responsibility (CSR)? Review of Islamic Economics, 12(1).

Elkington, John. 1997. Cannibals with Forks : The Triple Bottom Line of 21st Century Business. Oxford: Capstone Publishing Ltd. 
Financial Accounting Standards Board (FASB) dalam Statement of Financial Concept (SFAC) No. 1

Ghozali, Imam. 2016. Aplikasi Analisis Multivariete Dengan Program IBM SPSS 23 (Edisi 8). Cetakan ke VIII. Semarang : Badan Penerbit Universitas Diponegoro.

Gunning R. 1952. The Technique of Clear Writing. McGraw-Hill: New York.

Haniffa, R. 2002. Social Reporting Disclouse: An Islamic Perspective. Indonesian Management \& Accounting Research.

Hendriksen, Eldon S., dan Brada Michael F. Van. 1991. Accounting Theory. Boston: Soutern Metodist University.

Icuk Rangga Bawono, Diana Supriati, dan Leonart Edo Adrianus Hasugian. 2019. The Effect of Corporate Social Responsibility Performance on the Readability of CSR Using Firm Size, Bussiness Complexity, Leverage, Growth, and CEO'S Characteristics as Control Variables. Advances in Economics, Business and Management Research, volume 127. Annual International Conference on Accounting Research (AICAR 2019).

Ishfaq Ahmed, Muhammad Zeeshan Shaukat dan Talat Islam. 2013. Mission statements readability: An insight into Islamic banks. Journal of Islamic Accounting and Business Research Vol. 4 No. 2, 2013 pp. 132-150.

Jensen, M., C., dan W. Meckling, 1976. Theory of the firm: Managerial behavior, agency cost and ownership structure, Journal of Finance Economic 3:305- 360.

Jin-hui Luo,Xue Li,Huayang Chen. 2018. Annual Report Readability and Corporate Agency Costs. China Journal of Accounting Research.

Kincaid JP, Fishburne RP, Rogers RL, Chissom BS. 1975. Derivation of new readability formulas (automated readability index, fog Count, and flesch reading ease formula) for navy enlisted personnel. Research Branch Report: 8-75.

Tinker, Miles A. 1963. Legibility of Print. Iowa: Iowa State University Press. pp. 5-7. ISBN 0-8138-2450-8.

Othman, R. dan Thani, A. M. 2010. Islamic Social Reporting Of Listed Companies In Malaysia. Interntional Business \& Economics Research Journal.

Ousama, A.A. dan Fatima, A.H. 2006. The determinants of voluntary disclosure in the annual reports by Shariah-Approved companies listed on Bursa Malaysia. Paper presented at IIUM International Accounting Conference 3, Malaysia, 26-28 June.

Scherer, A.G. and Palazzo, G. 2011. The new political role of business in a globalized world: review of a new perspective on CSR and its implications for the firm, governance, and democracy. Journal of Management Studies, Vol. 48 No. 5, pp. 899-931.

Shuili Du dan Kun Yu. 2020. Do Corporate Social Responsibility Reports Convey Value Relevant Information?. Evidence from Report Readability and Tone. Journal of Business Ethics

Sugiyono. 2013. Metodelogi Penelitian Kuantitatif, Kualitatif Dan R\&D. Bandung: Alfabeta. 
Tinker, Miles A. 1963. Legibility of Print. Iowa: Iowa State University Press. pp. 5-7. ISBN 0-8138-2450-8.

Zhihong Wang, Tien-Shih Hsieh dan Joseph Sarkis. 2017. CSR Performance and the Readability of CSR Reports: Too Good to be True?. Corporate Social Responsibility and Environmental Management Corp. Soc. Responsib. Environ. Mgmt.

Undang-Undang Nomor 40 Tahun 2007 tentang Perseroan Terbatas Undang-Undang Nomor 25 Tahun 2007 tentang Penanaman Modal www.isoindonesiacenter.com

www.kominfo.go.id 